\title{
Primary hyperparathyroidism due to mediastinal parathyroid lesions
}

\author{
Jacek Gawrychowski, Grzegorz Buła, Zbigniew Niedzielski, Agata Gawrychowska, Adam Bednarczyk, \\ Grzegorz Kowalski
}

Department of General and Endocrine Surgery, Medical University of Silesia, Katowice, Poland

Kardiochir Torakochir Pol 2021; 18 (1): 55-59

Parathyroidectomy (PTX) is the treatment of choice, with a cure rate of $95-98 \%$ in expert centres [1, 2]. Commonly inadequate resection is caused by ectopic glands. Mostly they are found in the superior mediastinum among the thymus gland and can be excised by a collar incision [3].

A mediastinal parathyroid (MP) is determined as a gland found completely below the level of the clavicle. Approximately $15-20 \%$ of abnormal parathyroid glands are found in the mediastinum. Ectopic inferior parathyroids are frequently located in the anterior mediastinum, usually in the thymus gland, while superior parathyroids are found in the posterosuperior mediastinum. Less commonly they may be located in the aortopulmonary window and rarely in the pericardium [4-6].

We report 4 patients operated by upper median sternotomy for primary hyperparathyroidism (PHP) due to ectopic mediastinal lesions.

Between the years 1983 and 2018 a total of 1019 patients underwent surgery for PHP at our institution. Among this group of patients 66 (6.5\%) were operated for ectopic lesions localized in the mediastinum. In 62 (94\%) patients the ectopic lesions were excised via cervicotomy, 4 of whom required an upper median sternotomy approach. There were 2 women and 2 men, aged 22-72, mean 52.5 years. The diagnostic and surgical approaches used for our 4 patients are shown in Table I.

All patients diagnosed for PHP were referred to our department for further treatment, from other centres. Apart from one woman admitted for threatened hypercalcaemic crisis $(1.63 \mathrm{mmol} / \mathrm{l})$, the reminder had scintigraphy Tc99MIBI/SPECT performed.

Patient 1: This was a 72-year-old woman who complained of general weakness, consciousness disorders, and bone pain. A ultrasonography (USG) of the neck revealed multinodular thyroid gland and probably enlarged left upper parathyroid gland $(11 \times 7 \mathrm{~mm})$. During the operation both upper parathyroid glands were removed. No lower parathyroid gland was seen and ionized parathormone level (iPTH) did not decrease; near total thyroidectomy was performed. After the operation her condition worsened and on the $7^{\text {th }}$ postoperative day helical computed tomography (CT) scanning was performed. The examination revealed a mass $30 \times 20 \times 20 \mathrm{~mm}$ in the aorto-pulmonary window. Moreover, pathologic fracture Th8-Th9 was seen. She was re-operated the next day, and the lesion was excised. The post-operative period was complicated with bilateral pneumonia and serious hypocalcaemia. On day 27 , after the second operation, the woman was discharged to her previous hospital in a good condition, where she spent next 16 days with a recommendation to take calcium. She survived 7 years under oncological supervision, until in August 2016 she was lost from observation.

Patient 2: This was a 22-year-old man treated without success for a renal stones and renal insufficiency. During treatment it was noticed that his serum ionized calcium level (iCa) had risen $(2.13 \mathrm{mmol} / \mathrm{l})$, creatinine was elevated to $2.46 \mathrm{mg} / \mathrm{dl}$, and glomeruralar filtration rate (GFR) dropped to $35 \mathrm{ml} / \mathrm{min} / 1.73 \mathrm{~m}^{2}$. Scintigraphy with Tc99msestamibi showed an extrathyroidal accumulation area projected onto the superior mediastinum located slightly left of the median line (Figure $1 \mathrm{~A}$ ). A one-stage operation (cervicotomy and middle superior sternotomy) was carried out, with positive biochemical effect. A parathyroid lesion $20 \times 21 \times 25 \mathrm{~mm}$ was found hidden inside the left lower thymus horn and surrounded by the pleura. On the first post-operative day he complained of abdominal pain, partly in the upper abdominal area, radiating to the back with nausea and abdominal distention. The physical examination findings revealed mild tenderness of the whole abdomen and distention. Serum amylase level increased to $756.6 \mathrm{IU} / \mathrm{l}$, glucose $165 \mathrm{mg} \%$, serum lactate dehydrogenase (LDH) 365 IU/l, C-reactive protein (CRP) 178.6, creatinine $3.6 \mathrm{mg} / \mathrm{dl}$, white blood cells (WBC) 17,200 cells $/ \mathrm{mm}^{3}$, aspartate transferase (AST) $275 \mathrm{U} / 100 \mathrm{ml}$, and bilirubin $3.6 \mathrm{mg} \%$. CT examination showed grade C according to the Balthazar-Ranson grading system. They returned to normal on the $14^{\text {th }}$ postoperative day. The patient recovered and was discharged on the $22^{\text {nd }}$ post-operative day. USG and CT examinations performed before he left the hospital revealed pancreatic pseudocyst. He is currently

Address for correspondence: Prof. Jacek Gawrychowski, Department of General and Endocrine Surgery, Medical University of Silesia,

Katowice, Poland, e-mail: chirurgiabytom@sum.edu.pl

Received: 14.10.2020, accepted: 16.01.2021. 
Table I. The diagnostic and surgical approaches

\begin{tabular}{|c|c|c|c|c|}
\hline \multirow[t]{2}{*}{ Factor } & \multicolumn{4}{|c|}{ Patient } \\
\hline & 1 & 2 & 3 & 4 \\
\hline Sex, age & Female, 72 & Male, 22 & Female, 54 & Male, 62 \\
\hline $\begin{array}{l}\text { PTH } \\
15-65 \mathrm{pg} / \mathrm{ml}\end{array}$ & 808 & 906.7 & 197 & 359.4 \\
\hline $\begin{array}{l}\mathrm{Ca}^{2+} \\
1-1.28 \mathrm{mmol} / \mathrm{l}\end{array}$ & 1.63 & 2.13 & 1.36 & 1.7 \\
\hline $\begin{array}{l}\text { Creatinine } \\
0.4-1.24 \mathrm{mg} / \mathrm{dl}\end{array}$ & 0.56 & 2.46 & 1.36 & 1.04 \\
\hline $\begin{array}{l}\mathrm{Na}^{+} \\
135-148 \mathrm{mmol} / \mathrm{l}\end{array}$ & 140 & 137 & 142 & 139 \\
\hline $\begin{array}{l}\mathrm{K}^{+} \\
3.4-5 \mathrm{mmol} / \mathrm{l}\end{array}$ & 4.94 & 4.49 & 4.7 & 4.61 \\
\hline GFR $>60 \mathrm{ml} / \mathrm{min} / 1.73 \mathrm{~m}^{2}$ & 58.9 & 35 & 67.6 & 77.4 \\
\hline Imaging examination & USG, after I operation CT & Scintigraphy MIBI/SPECT & Scintigraphy MIBI/SPECT & Scintigraphy \\
\hline Complaints & $\begin{array}{c}\text { General weakness, } \\
\text { consciousness disorders, } \\
\text { bone pain }\end{array}$ & $\begin{array}{l}\text { Renal stones, renal } \\
\text { insufficiency }\end{array}$ & $\begin{array}{c}\text { Renal stones, } \\
\text { hypertension, weakness, } \\
\text { bone pain, walking } \\
\text { troubles }\end{array}$ & $\begin{array}{c}\text { Weakness, fatigue, bone } \\
\text { pain }\end{array}$ \\
\hline \multirow[t]{2}{*}{ I Operation } & 7.05 .2009 & 13.09.2010 & 1.09 .2017 & 12.10 .2018 \\
\hline & Cervicotomy & $\begin{array}{l}\text { One-stage cervicotomy + } \\
\text { upper middle sternotomy }\end{array}$ & Cervicotomy & $\begin{array}{l}\text { One-stage cervicotomy }+ \\
\text { upper middle sternotomy }\end{array}$ \\
\hline PTH [pg/ml] & 726.5 & 10.5 & 151.6 & 11.3 \\
\hline $\mathrm{Ca}^{2+}[\mathrm{mmol} / \mathrm{l}]$ & 1.56 & 1.13 & 1.42 & 1.21 \\
\hline Hist.-pat. & Hyperplasia & Adenoma & Not found & Hyperplasia \\
\hline \multirow[t]{2}{*}{ II Operation } & 15.05.2009 & & 10.01 .2019 & \\
\hline & Upper middle sternotomy & & Upper middle sternotomy & \\
\hline PTH [pg/ml] & 5.74 & & 32.6 & \\
\hline $\mathrm{Ca}^{2+}[\mathrm{mmol} / \mathrm{l}]$ & 1.05 & & 1.12 & \\
\hline Hist.-pat. & Carcinoma & & Hyperplasia & \\
\hline Dimension [mm] & $30 \times 20 \times 20$ & $20 \times 21 \times 5$ & $10 \times 15 \times 20$ & $50 \times 40 \times 30$ \\
\hline Complications & $\begin{array}{l}\text { Bilateral pneumonia, } \\
\text { persistent hypocalcaemia }\end{array}$ & $\begin{array}{c}\text { Acute pancreatitis } \\
\text { (grade C according to } \\
\text { Balthazar-Ranson grading } \\
\text { system) }\end{array}$ & $\begin{array}{l}\text { Left pneumothorax (chest } \\
\text { tube was removed on } 3^{\text {rd }} \\
\text { postoperative day) }\end{array}$ & $\begin{array}{l}\text { Right pneumothorax } \\
\text { (chest tube was removed } \\
\text { on } 3^{\text {rd }} \text { postoperative day) }\end{array}$ \\
\hline Discharge [day] & 27 & 22 & 9 & 8 \\
\hline Alive & $\begin{array}{l}\text { Lost from observation } \\
\text { in } 2016\end{array}$ & Yes & Yes & Yes \\
\hline
\end{tabular}

alive. A control CT scan showed that the pseudocyst has diminished.

Patient 3: This was a 54-year-old woman diagnosed during laboratory screening. She complained of renal stones and hypertension. A sestamibi scan revealed a single focus of increased tracer accumulation in the anterior mediastinum. Unfortunately, before operation, the patient refused sternal approach, following failed cervicotomy, and allowed only the collar incision. After the cervicotomy, she once again refused the sternal approach. However, after 16 months she gave permission for sternotomy. The main complaints, such as bone pain, weakness, and walking troubles, increased. The upper middle sternotomy was done. A parathyroid lesion $10 \times 15 \times 20 \mathrm{~mm}$ was found hidden very deep between the main left bronchus posteriorly, the left pulmonary artery anteriorly, and $2 \mathrm{~cm}$ below the aortic arch, close to the aorta (Figure $1 \mathrm{~B}$ ). She is currently alive, under supervision, and in good condition.

Patient 4: A PHP was diagnosed during a routine laboratory screening in a 62-year-old man for complaints such as weakness, fatigue, and bone pain. A sestamibi examination demonstrated a single focus of increased tracer accumulation of the anterior mediastinum. During a 1-stage operation (cervicotomy and middle superior sternotomy) a huge lesion $50 \times 40 \times 30 \mathrm{~mm}$ was excised. It was found in the angle of the caval superior and the left brachiocephalic 

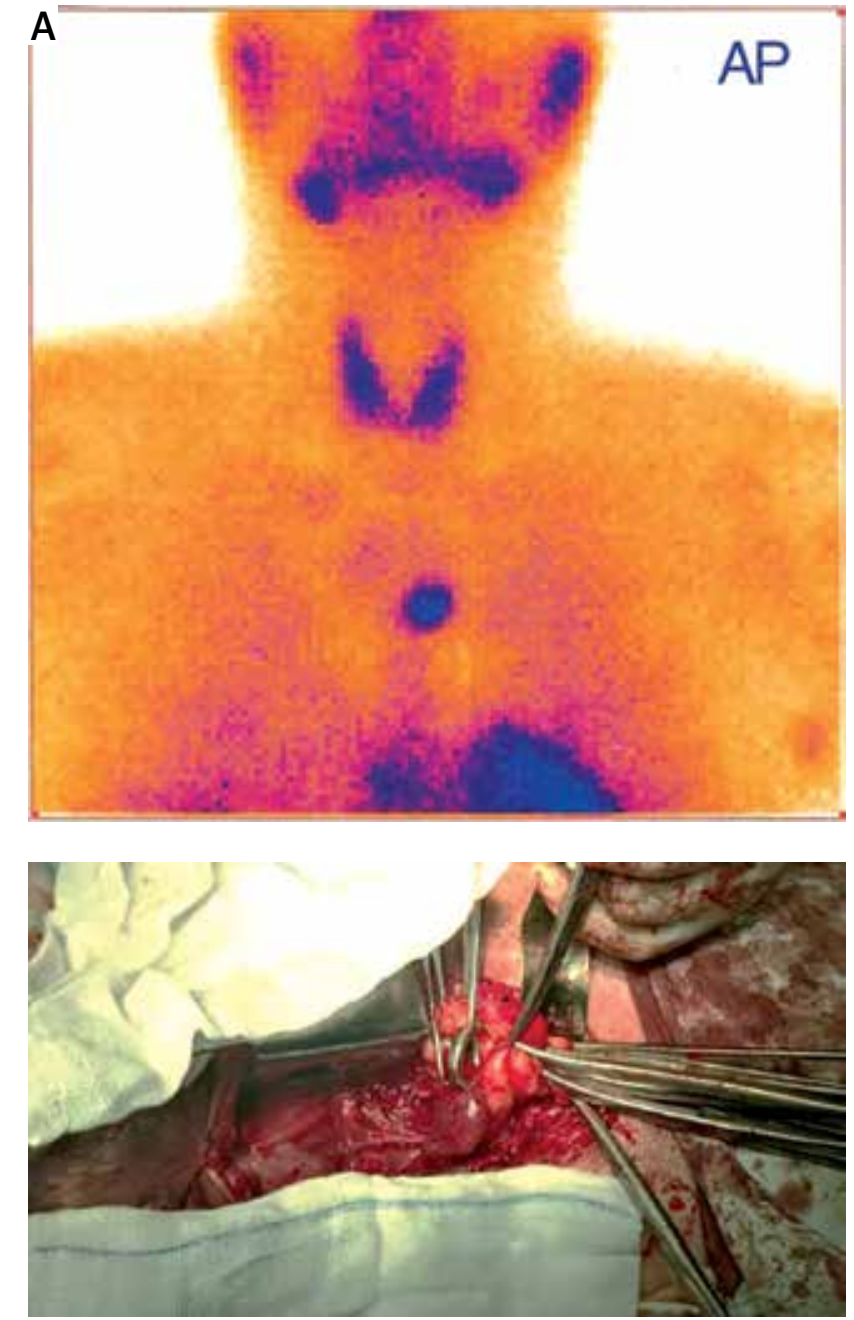

Figure 1. A - parathyroid adenoma located in the mediastinum. CT and MIBI scintigraphy (male age 22)

veins anteriorly and the aortic arch posteriorly. The patient recovered and was discharged on the $8^{\text {th }}$ post-operative day. He remains under supervision.

Mediastinal location is the most likely when the parathyroid gland has an ectopic position [3, 7]. Meta-analysis of a group of 7529 patients showed that $15.9 \%$ of parathyroid glands were present in ectopic locations, with more than $4 \%$ within the mediastinum [4]. Most ectopic mediastinal parathyroid glands are located in the thymus, or more often in the cervical tongue of the thymus in the anterosuperior mediastinum. Such lesions can be mostly removed through standard cervical approach; however, those located deeper require sternotomy. Others $[3,8]$ reported that in $1-2 \%$ of
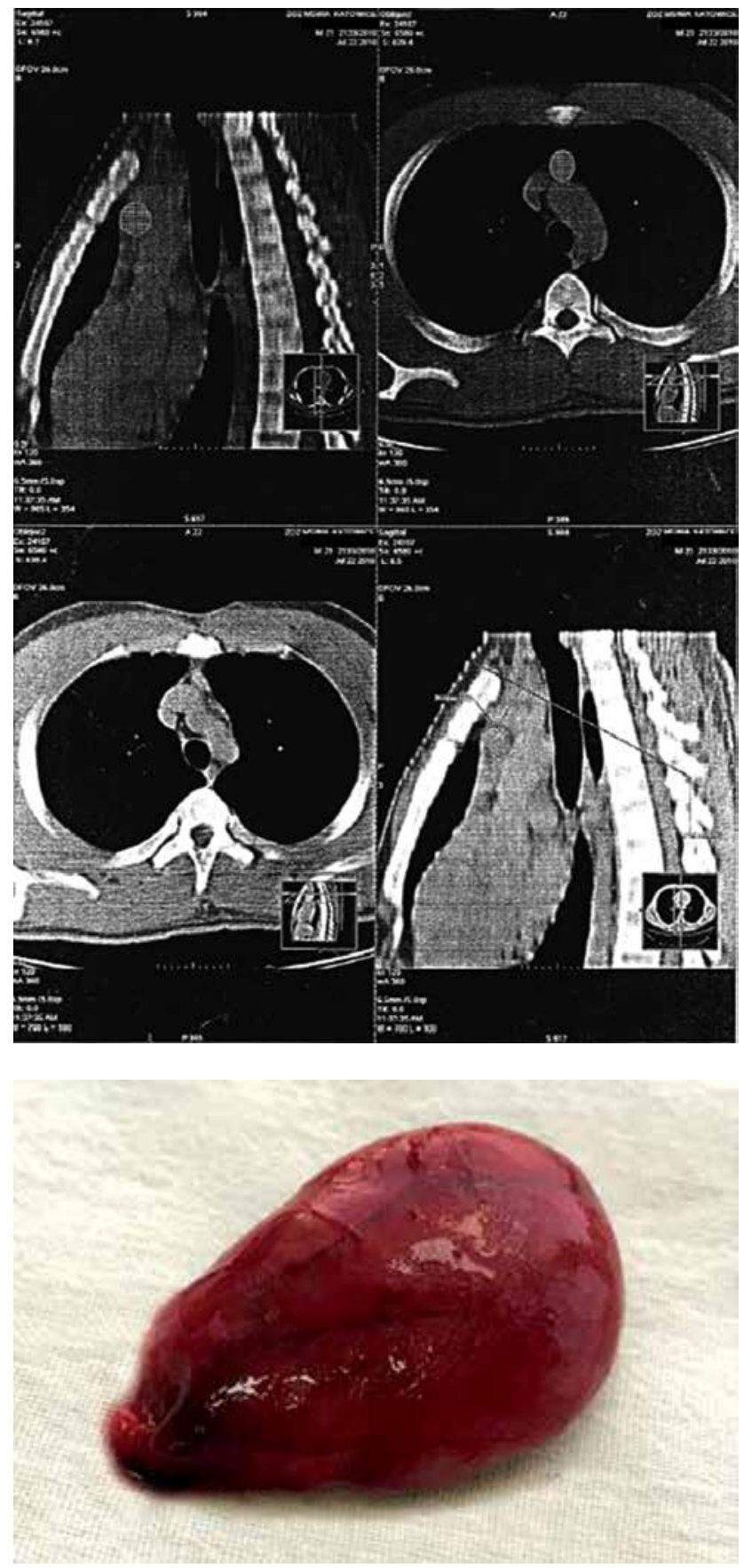

patients treated for PHP, sternotomy was necessary when parathyroid glands were located in the middle or posterior mediastinum, aortopulmonary window, or pericardium. Another reported that if the mediastinal parathyroid gland was located below the innominate vein, an open thoracic approach should be used [9].

Parathyroid changes found deep in the mediastinum remain a surgical challenge. For these lesions preoperative localization is crucial before mediastinal exploration. However, the optimal approach has not been determined. Unlike parathyroid changes in the neck, USG has not been proven useful in detecting mediastinal parathyroids. In such ectopic glands CT scan or magnetic resonance (MR) may be 

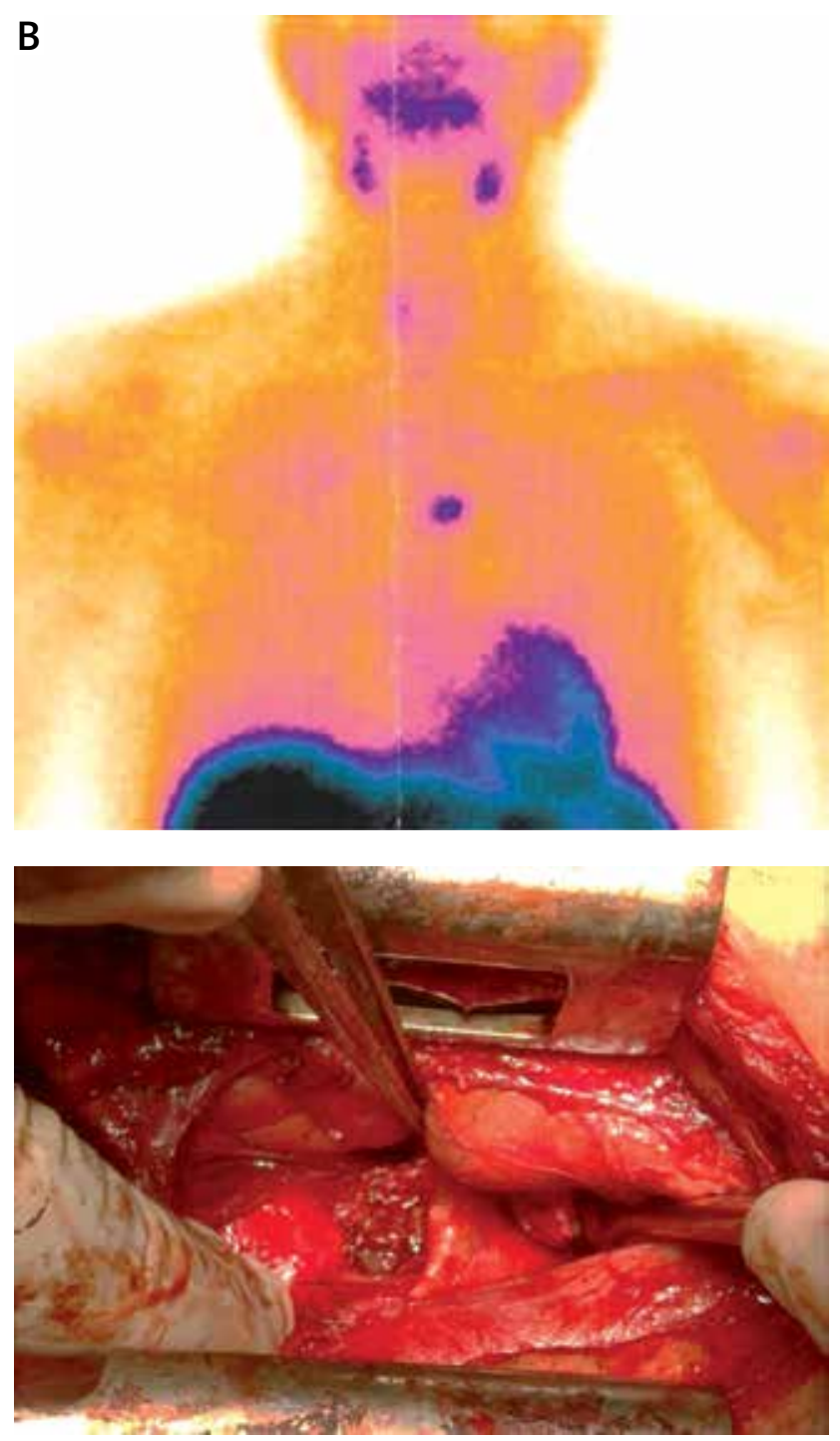

helpful. Single photon emission tomography (PET) can also improve localization, with up to $96 \%$ sensitivity $[8,10]$. For imaging of parathyroid lesions Tc99m-sestamibi has a very important benefit: it allows identification of smaller lesions than former examinations. So, the SPECT/CT remains the best imaging modality for preoperative localization of parathyroid lesions. If ectopic changes are suspected, addition of $4 \mathrm{D}-\mathrm{CT}$ is recommended. Actually, preoperative FCH PET/ $\mathrm{CT}$ has a high value for parathyroid lesions detections in patients with PHP [11, 12].

Some authors suggested the level of the aortic arch on the horizontal chest CT as a guideline for suitable surgical approach during PTX [13]. Another demonstrated that when the parathyroid lesion was located deeper than $6 \mathrm{~cm}$ below the clavicle head, a transcervical approach was effective only in $25 \%$ of cases [14]. All changes above the aortic arch in the antero-superior mediastinum can be treated successfully by transcervical approach, while those in the middle or posterior mediastinum can be cured by transthoracic approach [15]. On the other hand, $1-2 \%$ of patients will require a transsternal or transthoracic approach due to deeply

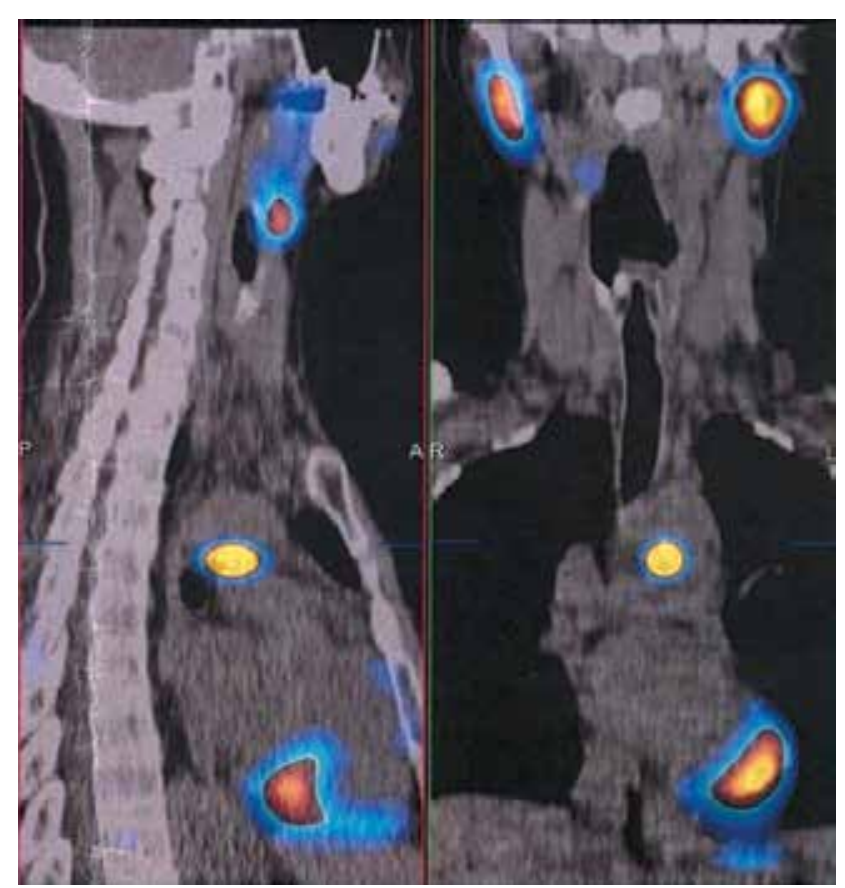

Figure 1. B - Parathyroid hyperplasia located in the mediastinum. $\mathrm{CT}$ and scitigraphy images (female age 54)

seated mediastinal lesions [16]. Our series confirmed that only a small number of patients require a direct sternal or thoracic approach, in accordance with other findings.

However, complete resection via a cervical approach might be difficult or impossible when the lesions are located in the lower part of the mediastinum below the innominate vein. The deep location in the middle mediastinum is the main risk condition for unsuccessful cervical approach. We agree with such observations $[13,15,16]$. Our series confirmed such findings that few patients require a direct sternal or thoracic approach. To reduce the invasiveness of full sternotomy we prefer upper middle sternotomy, which was done in 4 of our patients [17]. Three out of 4 of our patients had cervicotomy performed. Unfortunately, we did not find any parathyroid glands, and superior middle superior sternotomy was necessary. During such a procedure we cut the sternum for 5-7 cm only. This approach allowed us an excellent view of the middle mediastinum, particularly into the aorto-pulmonary window. Nevertheless, despite a higher risk of complications, sternotomy seems to be safe procedure. Among our patients we observed 2 incidences 
of one-sided pneumothorax and 1 incidence of pneumonia. After pleural cavity drainage, chest tubes were removed on the $3^{\text {rd }}$ postoperative day.

Some authors $[3,15,18]$ advocate a median complete sternotomy. They consider that only such drastic action gives a good view and makes it easy to palpate any other masses that are present in the mediastinal fat. Another advocates also anterior mediastinotomy (parasternal) with an $89 \%$ success rate, or thoracotomy [19]. In the last 2 decades less invasive approaches have been introduced, following new imaging techniques to identify ectopic lesions. Such procedures as video- and video-assisted thoracoscopy or robotic surgery reduce the rate of morbidity, shorten the stay in hospital, and significantly decrease pain, but palpation sensitivity is limited [20-22]. Moreover, unfortunately most thoracoscopic procedures are not accessible in endocrinal surgical centres. On the other hand, a review of thoracic centre reports shows up to $23 \%$ of failed operations for mediastinal location of the parathyroid glands [3, 15].

Upper middle sternotomy is still a good access in the search for ectopic parathyroid glands in the mediastinum.

\section{Disclosure}

The authors report no conflict of interest.

\section{References}

1. Gawrychowski J, Kowalski GJ, Buła G, Bednarczyk A, Żądło D, Niedzielski Z, Gawrychowska A, Koziołek H. Surgical management of primary hyperparathyroidism - clinicopathologic study of 1019 cases from a single institution. J Clin Med 2020; 9: 3540.

2. Van Heerden JA, Grant CS. Surgical treatment of primary hyperparathyroidism: an institutional perspective. World J Surg 1991; 15: 688-692.

3. Iacobone M, Mondi I, Viel G, Tropea S, Frego M, Favia G. The results of surgery for mediastinal parathyroid tumors: a comparative study of 63 patients. Langenbeck's Arch Surg 2010; 395: 947-953.

4. Taterra D, Wong LM, Vikse J, Sanna B, Pękala P, Walocha J, Cirocchi R, Tomaszewski K, Henry BM. The prevalence and anatomy of parathyroid glands: a meta-analysis with implications for parathyroid surgery. Langenbeck's Arch Surg 2019; 404: 63-70.

5. Phitayakorn R, McHenry CR. Incidence and location of ectopic abnormal parathyroid glands. Am J Surg 2006; 191: 418-423.

6. Arnault V, Beaulieu A, Lifante JC, Sitges Serra A, Sebag F, Mathonnet M, Hamy A, Meurisse M, Carnaille B, Kraimps JL. Multicenter study of 19 aortop- ulmonary window parathyroid tumors: the bchalenge of embryologic origin. World J Surg 2010; 34: 2211-2216.

7. LoPinto M, Rubio GA, Khan ZF, Vaghaiwalla TM, Farra JC, Lew JI. Location of abnormal parathyroid glands: lessons from 810 parathyroidectomies. J Surg Res 2017; 207: 22-26.

8. Karipineni F, Sahli Z. Somervell H, Mathur A, Prescott JD, Tufano RP, Zeiger MA. Are preoperative sestamibi scans useful for identifying ectopic parathyroid glands in patients with expected multigland parathyroid disease? Surgery 2018; 163: 35-41.

9. Nilubol N, Beyer T, Prinz R.A, Solorzano CC. Mediastinal hyperfunctioning parathyroids: incidence, evolving treatment, and outcome. Am J Sur 2007; 194: 53-56.

10. Patel SG, Sounders ND, JamshedS, Weber CJ, Sharma J. Multimodal preoperative localization Improves outcomes in reoperative parathyroidectomy: a 25- year surgical experience. Am Surg 2019; 85: 939-943.

11. Kedarisetty S, Fundakowski C, Ramakrishnan K, Dadparvar S. Clinical value of TC99m-MIBI SPECT/CT versus 4D-CT or US in management of patients with hyperparathyroidism. Ear Nose Throat J 2019; 98: 149-157.

12. Quak E, Blanchard D, Houdu B, Le Roux Y, Ciappuccini R, Lireux B, de Raucourt D, Grellard JM, Licaj I, Bardet S, Reznik Y, Clarisse B, Aide N. F18-choline $\mathrm{PET} / \mathrm{CT}$ guided surgery in primary hyperparathyroidism when ultrasound and MIBI SPECT/CT are negative or inconclusive: the APACH1 study. Eur J Nucl Med Mol Imaging 2018; 45: 658-666.

13. lihara M, Suzuki R, Kawamata A, Horiuchi K, Okanoto T. Thoracoscopic removal of mediastinal parathyroid lesions: selection of surgical approach and pitfalls of preoperative and intraoperative localization. World J Surg 2012; 36: 1327-1334.

14. Callender GG, Grubbs EG, Vu T, Hofstetter WL, Fleming JB, Woodburn KL, Lee JE, Evans DB, Perrier ND. The faalen one: the inferior parathyroid gland that descends into the mediastinum. J Am Coll Surg 2009; 208: 887-893.

15. Said SM, Cassivi SD, Allen MS, Deschamps C, Nichols FC $3^{\text {rd }}$, Shen KR, Wigle DA. Minimally invasive resection for mediastinal ectopic parathyroid glands. Ann Thorac Surg 2013; 96: 1229-1233.

16. Alesina PF, Moka D, Mahlstedt J, Walz MK. Thoracoscopic removal of mediastinal hyperfunctioning parathyroids glands; personal experience and review of the literature. World J Surg 2008; 32: 224-231.

17. Gawrychowski J, Gabriel A, Kluczewska E, Buła G, Lackowska B. Mediastinal parathyroid carcinoma: a case report. Pol J Endocrinol 2012; 63: 143-146.

18. Grozavu C, Pantile D. Primary hyperparathyroidism through an ectopic parathyroid adenoma. Chirurgia 2016; 111: 156-160.

19. Ravipati NB, McLemore EC, Schlinkert RT, Argueta R. Anterior mediastinotomy for parathyroidectomy. Am J Surg 2008; 214: 555-561.

20. Nagano H, Suda T, Ishizawa H, Negi T, Kawai H, Kawakami T, Tochii D, Tochii S, Hoshikawa Y. Video-assisted thoracoscopic surgery for ectopic mediastinal parathyroid tumor: subxiphoid and lateral thoracic approach. J Thorac Dis 2019; 11: 2932-2938.

21. Xiu Y, Zhao T, Wei B, Hua G, Jin M, Shen H, Liu X, Wang J, Wang Q. Intrapericardial parotid carcinoma: a case report. Endocrine 2020; 69: 456-460.

22. Mansour DE, Lee ME, D'Souza DM, Merritt RE, Kneuertz PJ. Robotic resection of ectopic parathyroid glands in the superior posterior mediastinum. J Laparoendosc Adv Surg Tech A 2019; 29: 677-680. 